\title{
Seepage Analysis of Mahananda Earthen Embankment at Chapai Nawabganj in Bangladesh
}

\author{
Md. Abdul Alim, Fahim Ahmed, Md. Sohidul Islam \\ Department of Civil Engineering, Rajshahi University of Engineering \& Technology (RUET), Rajshahi, Bangladesh
}

\section{Email address:}

sohidul11ruet@gmail.com (Md. S. Islam)

\section{To cite this article:}

Md. Abdul Alim, Fahim Ahmed, Md. Sohidul Islam. Seepage Analysis of Mahananda Earthen Embankment at Chapai Nawabganj in Bangladesh. American Journal of Engineering and Technology Management. Vol. 2, No. 1, 2017, pp. 1-6.

doi: 10.11648/j.ajetm.20170201.11

Received: January 24, 2017; Accepted: February 16, 2017; Published: March 25, 2017

\begin{abstract}
Embankments are structures that are used especially for water storage, energy production, and irrigation. The type of embankment depends on the purpose of storm water to be used such as detention and retention, ground water recharge, surface water harvesting, flood control etc. and the available soil material for construction. Broadly, two type of embankment can be assumed, namely, homogenous embankment and zoned embankment. In this study, seepage through an earthen embankment's body is investigated using analytical and computer approach. Seepage is investigated since seepage both in the embankment's body and under the foundation adversely affects embankment's stability. This study specifically investigated seepage in embankment's body. Mahananda embankment is a homogeneous earthen embankment built on the impervious foundation. In the line of the purpose of this research, the seepage rate in an earthen embankment is estimated by Geo-Studio software (SEEP/W). Soil parameters such as soil type, Atterberg limits, moisture content (w) and unit weight of soil $(\gamma)$, hydraulic conductivity $(\mathrm{k})$ have been determined using field and lab experiments. Dimensional analysis was used with helping of the theoretical results to develop an empirical equation in order to determine the quantity of seepage through homogenous earthen embankment without filter resting on impervious base. Also, Verify the SEEP/W results with an artificial model and compare with analytical methods.
\end{abstract}

Keywords: Hydraulic Conductivity, Seepage Analysis, Analytical Method, Geo-Studio Softwar

\section{Introduction}

An embankment is an artificial barrier usually constructed along a stream channel to hold the back water. Embankments should also have a drain or other waterwithdrawal facility for control the water level and to lower or drain the lake for normal maintenance and emergency purposes. Embankments are constructed especially for water supply, flood control, irrigation, energy production, recreation, etc. Broadly, two type of embankment can be assumed, namely, homogenous embankment and zoned embankment. This study is an investigation about seepage through the earth embankment.

An embankment, constructed primarily of compacted earth, either homogeneous or zoned, and containing more than $50 \%$ of earth. The materials are usually excavated or quarried from nearby sites, preferably within the reservoir basin. If the remaining materials consist of coarse particles, there is gradation in fineness from the core to the coarse outer materials. According to the materials located in the body of embankment, there is a seepage through the embankment's body. Seepage can occur under the embankment foundation, too. In this research, seepage through the embankment's body was investigated.

Seepage is very important, as seepage affects the stability of embankment. Because of its importance, the determination of the seepage through an earth embankment has received a great deal of attention. Of primary concern is the location of the surface seepage on the downstream toe of the embankment.

There is seepage in the embankment's body following a phreatic line. This seepage must be limited, and phreatic line is important in order to understand the degree of seepage. If the surface seepage intersects the face of the 
embankment, erosion may result and possible failure of the embankment. Thus, it is necessary to measure the level of phreatic line and rockfills are used at the downstream toe or gravel blankets to intersect the line of seepage before it reaches the downstream toe.

Up to now, seepage under the embankment foundation is usually investigated. However, in this research seepage through the earthen embankment's body was investigated. The SEEP/W (Geo-studio 2012) computer software can also be used to estimate the seepage. Nomirov researched on the water seepage control through the isotropichomogenous earth embankments and represented a suitable method to solve the seepage problem through the earth embankment. Nomirov used the advanced mathematical relations to compute the characteristics of seepage in the isotropic embankment profile which has a downstream horizontal drainage. But Nomirov's method has defects and errors which were used in his equations. In this article, Seep/W software is used to analyze the foundation and body seepage. Aubertin et al. (1996) used this software to solve the unsaturated problems of multilayer covers is infinite aquifer pumping test. This software solves the underground water problems for stable, unstable, saturated and un-saturated conditions. Chapuis et al. (2002) researched on estimation of seepage discharge ratio through the embankment dams. It can be gained good results by using the Seep/W software. This software not only has the superiority to the graphic method and manual calculation, but also regarding the time we can gain good results. This software has many applications which helps designers in best designing of embankments and analyzing the weak or strength points of embankments and also designing of the construction which dealing with the seepage problems.

\section{Objectives}

1. To study the geometry of earthen embankment details.

2. To calculate the seepage discharge in earthen embankment by the analytical approach.

3. To analysis seepage discharge in earthen embankment by using Geo-Studio software.

\section{Location of the Study Area}

Mahanada earth embankment is located at Mohipur upzilla under Chapai Nawabgonj district, Bangladesh. The location of the embankment is Latitude 24.70 \& Longitude 88.26. The soil sample was collected from Diar Dhainagor Road.

\subsection{Materials}

The embankment of Mahananda river in Chapai Nawabganj is constructed mainly clay, sand, gravel materials. The clay soils are filled on upstream side and gravel soil is filled on downstream side and the sand layer is used for the purpose of to drain out the seepage of water from the embankment.

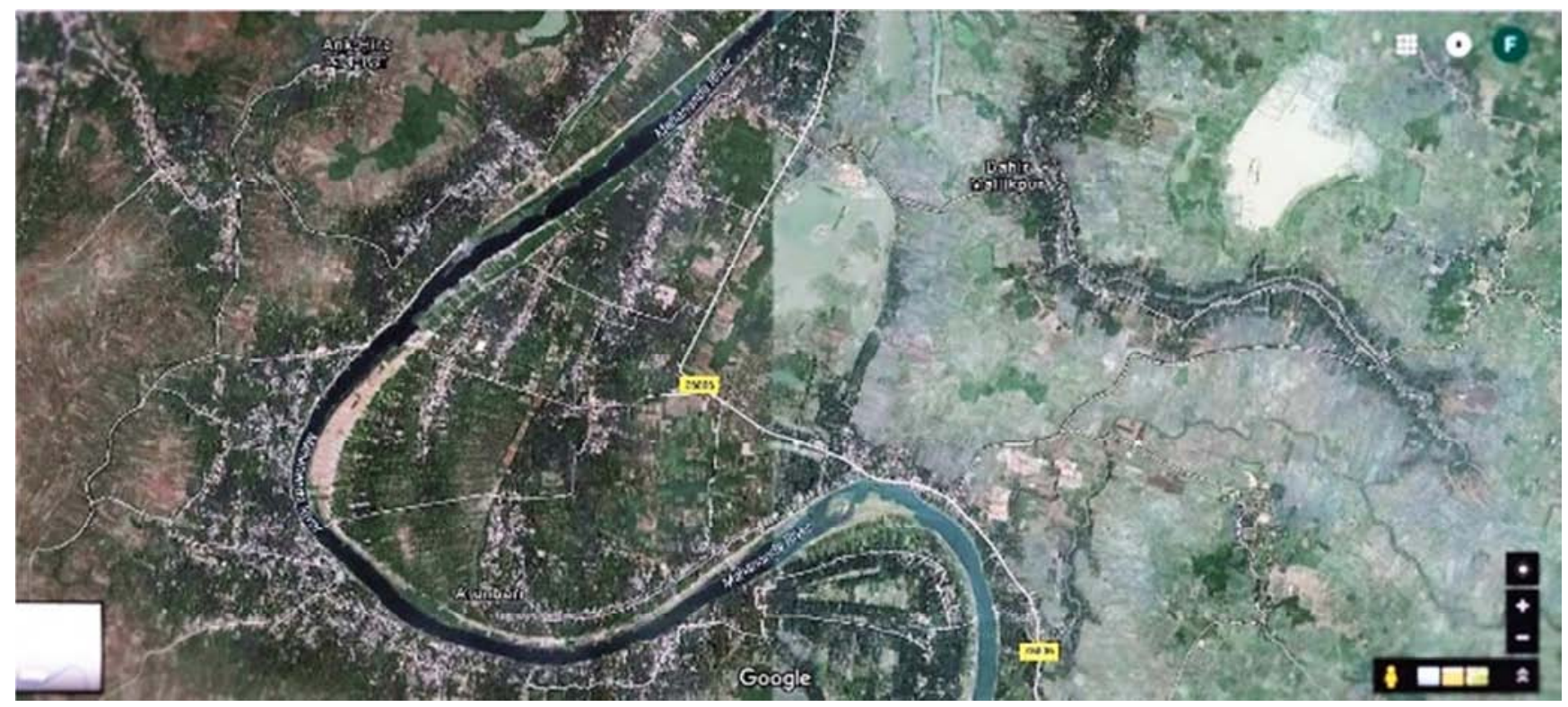

Figure 1. Location of Mahananda earthen embankment. 


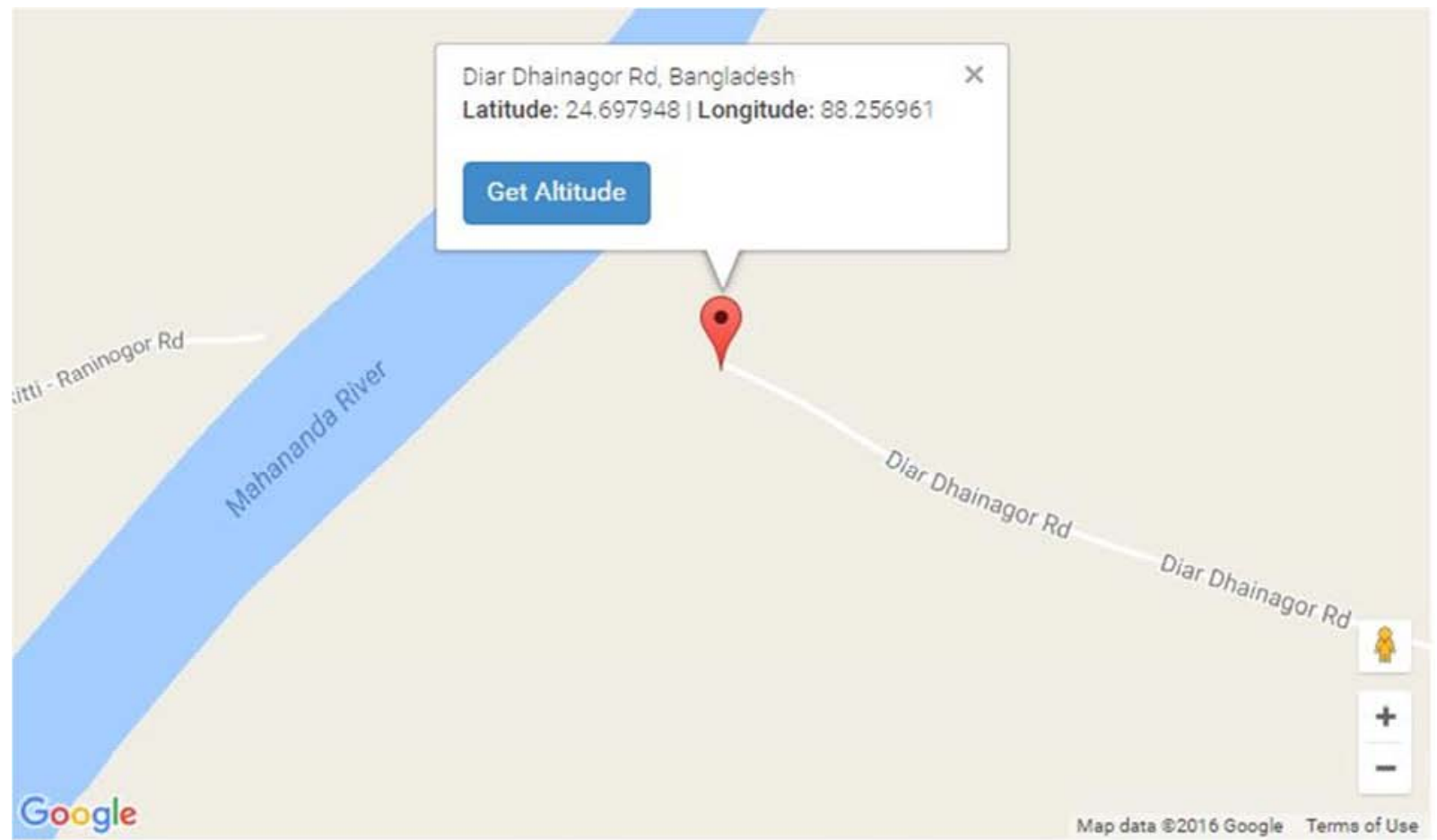

Figure 2. Longitude and Latitude of Mahananda earthen embankmen.

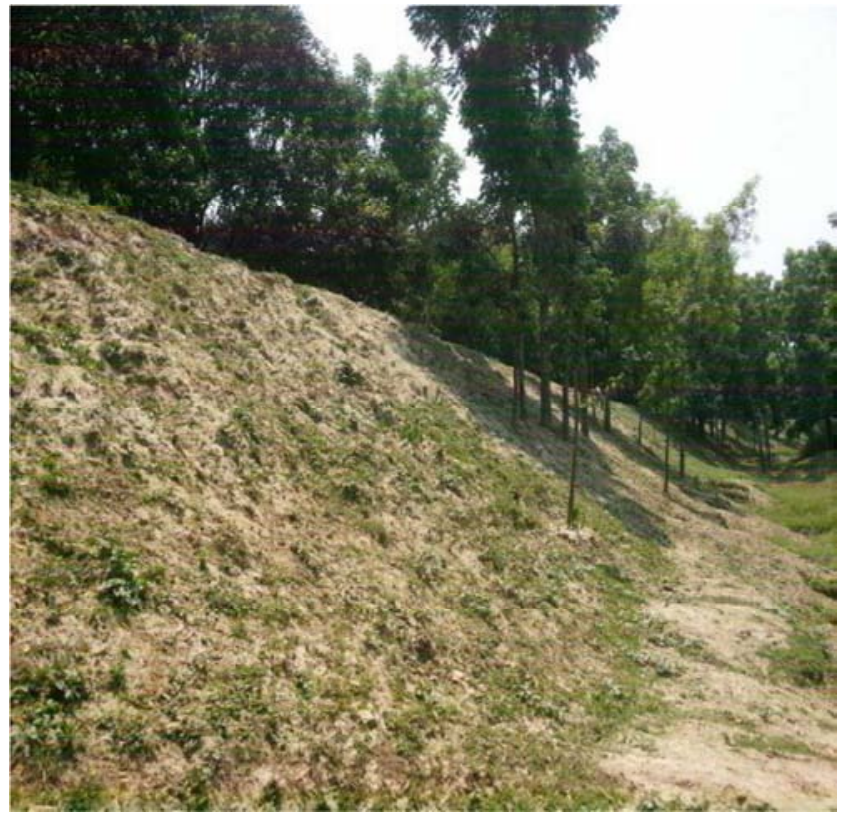

Figure 3. Sample collection.

Field density was determined in the site and the value obtained $18.75 \mathrm{KN} / \mathrm{m}^{3}$.

\section{Laboratory Test}

1. Specific gravity

2. Atterberg test

3. Grain size analysis

4. Water content

\section{Permeability Test}

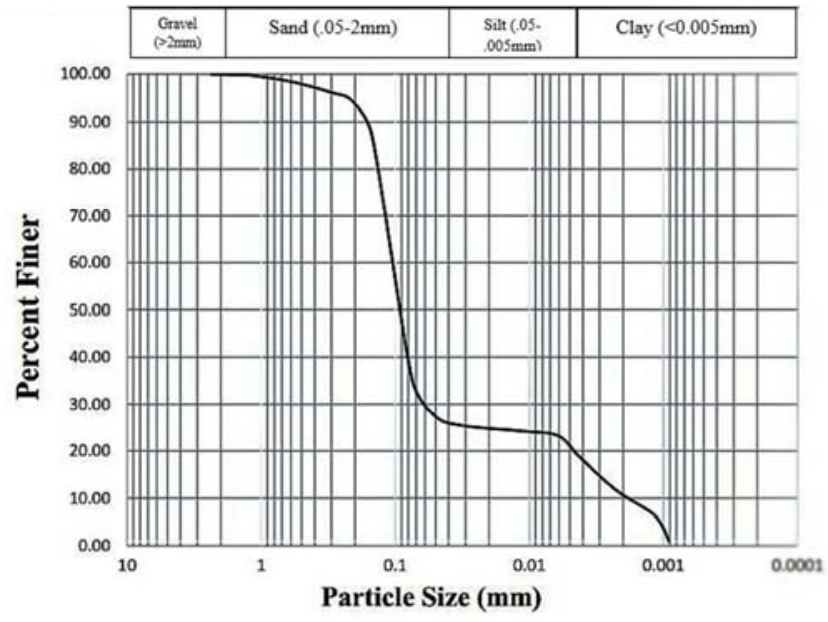

Figure 4. Grain Size Distribution Curve.

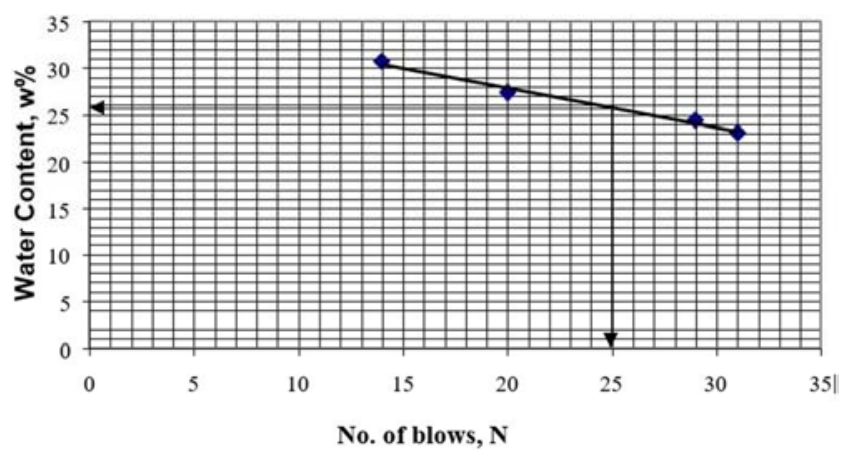

Figure 5. Determination of liquid limit. 
Table 1. Index properties of soil.

\begin{tabular}{ll}
\hline Index Property & Constituents \\
\hline Field Density & $1889.60 \mathrm{~kg} / \mathrm{m}^{3}$ \\
Water content & $13.16 \%$ \\
Specific Gravity & 2.754 \\
$\mathrm{D}_{60}$ & $0.2 \mathrm{~mm}$ \\
$\mathrm{D}_{30}$ & $0.07 \mathrm{~mm}$ \\
$\mathrm{D}_{10}$ & $0.002 \mathrm{~mm}$ \\
Soil Type & Sandy clay loam \\
Liquid Limit & $26 \%$ \\
Plastic Limit & $15 \%$ \\
Hydraulic conductivity (constant head method) & $1.93 \times 10^{-5} \mathrm{ft} / \mathrm{sec}$ \\
\hline
\end{tabular}

\subsection{Methodology}

Failure of embankment mainly occurred by increase of seepage pressure. Increase of seepage rate is mainly caused by rising of water level during rainy season. Our study is to motivate and evaluate the seepage through, the embankment of Mahananda river in Chapai Nawabganj Bangladesh. The method of investigation of this study was carried out into distinct phases, which were based on field and laboratory studies. For this study three most vulnerable sections of the embankment were identified. Obtained laboratory test data of embankment soil were used to build artificial section of embankment to measure the seepage rate and analyzed by Geo-studio software. In this project the seepage analysis is done in two ways (i) Analytical approach (ii) Computer approach.

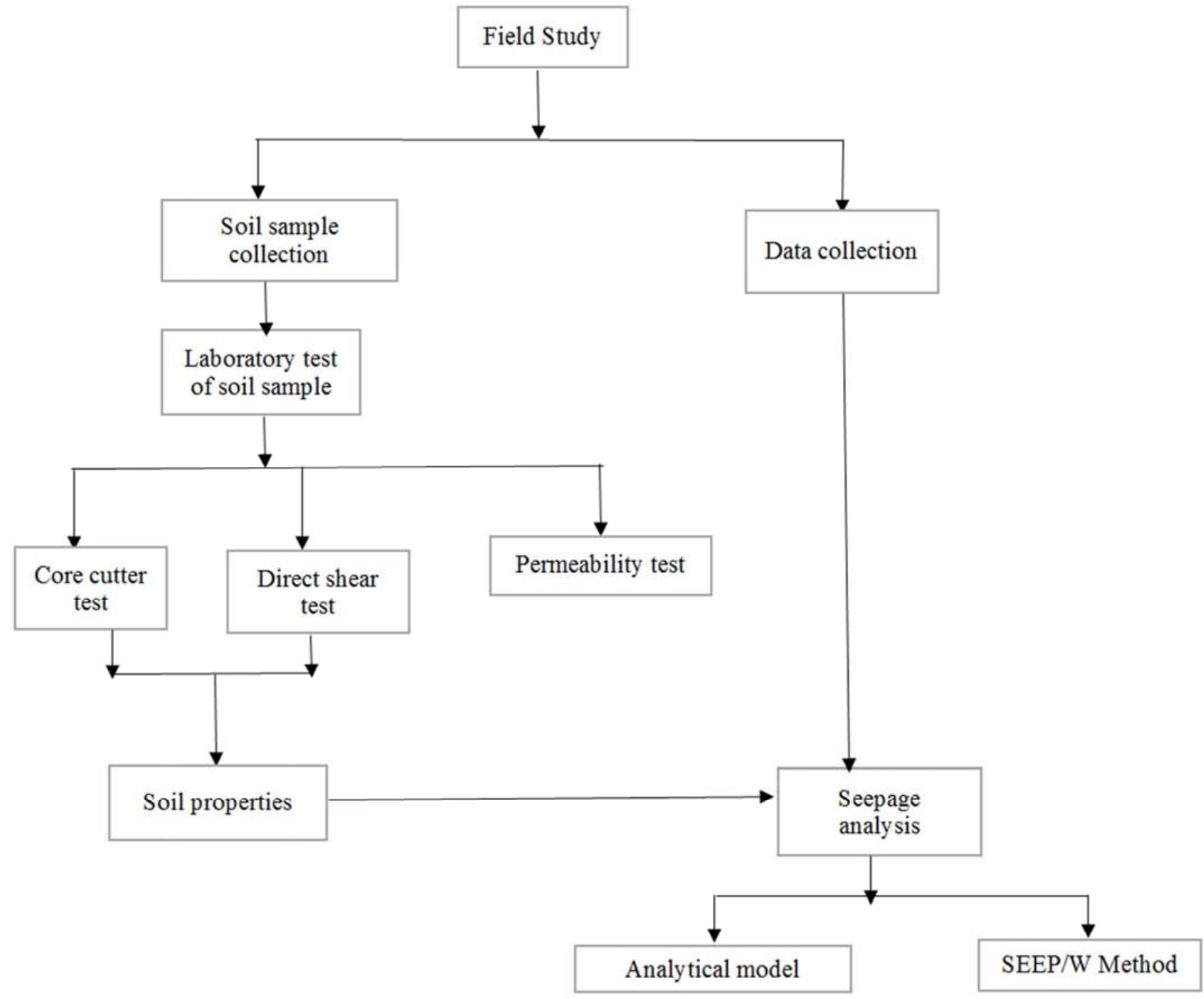

Figure 6. Diagram of working procedure.

\subsection{Model Application}

We prepared an artificial embankment model with soil sample which was collected from Mahananda embankment,
Chapai Nawabganj, Rajshahi. 


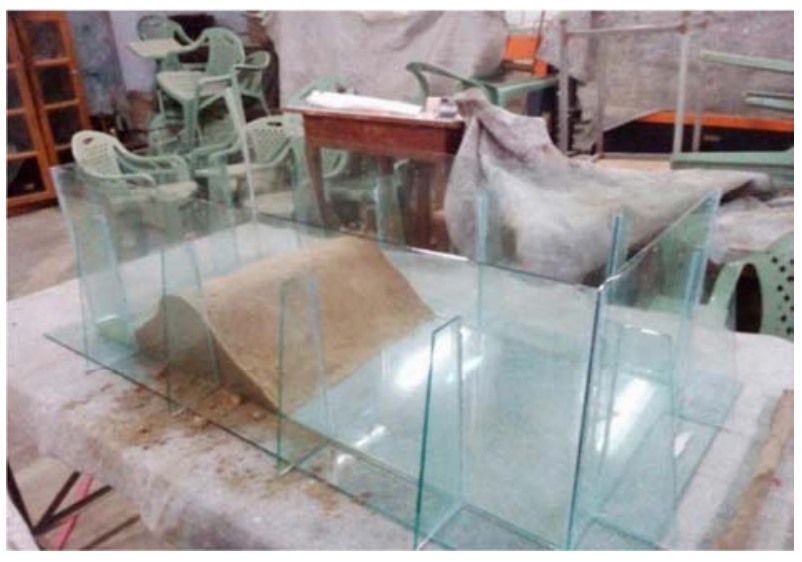

Figure 7. Model of an artificial embankment.

Table 2. Dimension of artificial earth embankment.

\begin{tabular}{ll}
\hline Bottom Width & $\mathbf{1 4 . 8 5}$ inch \\
\hline Top Width & 1 inch \\
Length & 18 inch \\
Total Height & 5.80 inch \\
Height of Water Level & 4.50 inch \\
Free board & 1.30 inch \\
Slope of the dam body & 1 in 1.20 \\
\hline
\end{tabular}

\subsection{Computer Approach}

In order to achieve the objectives of this study, Geo-studio software is used. The Geo-studio software is mainly based on finite element method that can be used for evaluate the performance of embankment. The Geo-studio software is suitable for eight products. SLOPE/W for slope stability, SEEP/W for ground water seepage, SIGMA/W for stressdeformation, QUAKE/W for dynamic earthquake, TEMP/W for geothermal, CTRAN/W for contaminant transport, AIR/W for air flow, VADOSE/W for vadose zone \& covers. In this research $\mathrm{SEEP} / \mathrm{W}$ is used. The product $\mathrm{SEEP} / \mathrm{W}$ is used for the analysis of seepage. Calculate the leak using partial differential equations makes the water flow. Geostudio software is mostly obtained in obtained inside varies civil engineering applications along with its problem analysis from considering other consideration. Now a days it's widely used the particular usually are mostly intended for finite element analysis, slope stability, seepage analysis so at some other applications obtained Geo-studio 2012 software. For seepage analysis the Geo-studio SEEP/W define module is used.

\section{Result and Discussion}

\subsection{Seepage Analysis by Analytical Method}

Rate of seepage, $\mathrm{q}=1.91 * 10^{-4} \mathrm{ft}^{3} / \mathrm{sec} / \mathrm{ft}$

\subsection{Seepage Analysis by Artificial Embankment Model}

Rate of seepage, $\mathrm{q}=1.06 * 10^{-5} \mathrm{ft}^{3} / \mathrm{sec} / \mathrm{ft}$

\subsection{Seepage Analysis by Computer Approach}

Table 3. Input parameters for computer approach.

\begin{tabular}{ll}
\hline Input parameters & Values \\
\hline Soil type & Sandy clay loam \\
Hydraulic conductivity & $1.93 * 10^{-5} \mathrm{ft} / \mathrm{sec}$ \\
Water content & $13.16 \%$ \\
Liquid limit & $26 \%$ \\
$\mathrm{D}_{60}$ & $0.2 \mathrm{~mm}$ \\
$\mathrm{D}_{10}$ & $0.002 \mathrm{~mm}$ \\
\hline
\end{tabular}

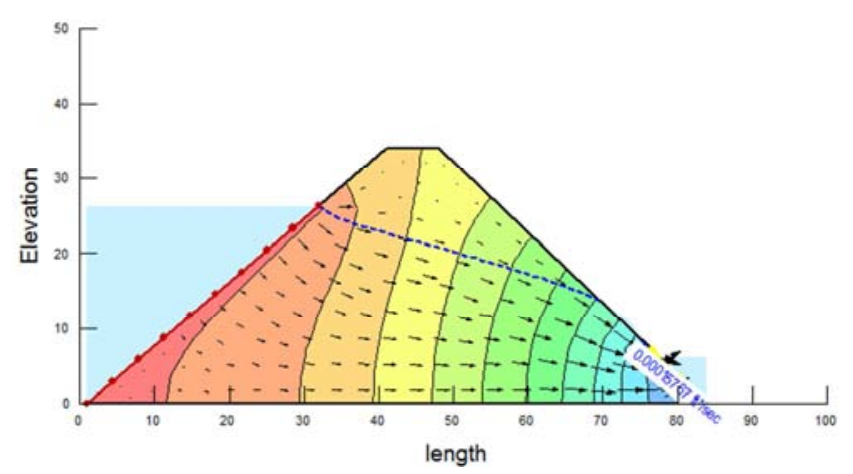

By computer approach seepage rate, $\mathrm{q}=1.57 * 10^{-4} \mathrm{ft}^{3} / \mathrm{sec} / \mathrm{ft}$

Figure 8. Seepage analysis by Geo-Studio software.

Table 4. Comparision of seepage rate.

\begin{tabular}{lll}
\hline Analysis by different approach & $\begin{array}{l}\text { Seepage rate } \\
\left(\mathbf{f t}^{\mathbf{3}} / \mathbf{s e c} / \mathbf{f t}\right)\end{array}$ & $\begin{array}{l}\text { Seepage rate } \\
\left(\mathbf{m}^{\mathbf{3}} / \mathbf{s e c} / \mathbf{m}\right)\end{array}$ \\
\hline $\begin{array}{l}\text { Analytical approach } \\
\text { Computer approach }\end{array}$ & $1.91 * 10^{-4}$ & $1.77 * 10^{-5}$ \\
$\begin{array}{l}\text { Artificial model }(13.16 \% \text { water } \\
\text { content) }\end{array}$ & $1.57 * 10^{-4}$ & $1.46 * 10^{-5}$ \\
\hline
\end{tabular}

\section{Discussion}

Study the existence problems in the earthen embankment. The seepage rate by analytical approach and computer approach is nearly similar but varies with artificial model. The particular reason for variation is scaling of the embankment. The model was constructed by reducing the scale. Analytical result was calculated by Darcy's law. For using dimensional analysis theorem with the help of the SEEEP/W results, an empirical equation has developed for determine the quantity of seepage through homogenous earthen embankment without filter resting on impervious base.

\section{Conclusion}

Seepage through embankment of Mahananda river has been investigated by analytical approach, artificial model and Geo-Studio software. The result obtained by these approach are nearly similar. The study indicates that, existing slope is not safe. From analysis, it is found that, failure occurs if water will rise upto $25 \mathrm{ft}$ high during rainy season. The downstream toe of the embankment may be eroded due seepage. The embankment can be stabilized by one of the following methods: 
- Providing a berm at downstream side.

- Providing a gravel filter at toe of the slope.

As future work, when longer period of observation and as well as data physical characteristics of the embankment become available by the performance of the Geo-Studio software may be further improved.

\section{References}

[1] Das, M. B. (1995) "Principle of Foundation Engineering" $4^{\text {th }}$ edition, PWS Publishing Company, Boston.

[2] Das, M. B. (1998) "Principle of Geotechnical Engineering" $4^{\text {th }}$ edition, PWS Publishing crop, USA.

[3] Santosh Kumar Garg (1976) "Irrigation Engineering and Hydraulic Structures" $21^{\text {st }}$ revised edition, Khanna Publishers, New Delhi.

[4] ASTM (1989), "Annual Book of ASTM Standards", Volume 04.08, Soil and Rock, Building Stones; Geotextiles.

[5] Kalkani, E. C. 1997. "Geological Conditions, Seepage Grouting, and Evaluation of Piezometer Measurements in the Abutments of an Earth Dam”, Engineering Geology. Vol. 46, pp. 93-104.

[6] Punmia B. C. (2001) "Soil Mechanics \& Foundation", Laxmi Publication Private Limited, New Delhi.

[7] Haussmann, M. R. and McGraw-Hill (1990), Engineering principles of ground modification.
[8] Leontiev, A. and Huacasi, W., 2000. "Mathematical Programming Approach for Unconfined Seepage Flow Problem", Engineering Analysis with Boundary Elements. Vol. 25, pp. 49-56.

[9] Marino, M. and Luthin, J. N., 1982. Seepage and Groundwater, (Elsevier Scientific Publishing Company, New York), pp. 107-112.

[10] Childs, E. C., and Collis-George, N., 1950. The Permeability of Porous Materials. Proceedings of the Royal Society, pp. 392-405.

[11] Green, R. E. and Corey, J. C., 1971. Calculation of Hydraulic Conductivity: A Further Evaluation of Some Predictive Methods. Soil Science Society of America Proceedings, Vol. 35, pp. 3-8.

[12] Ho, P. G., 1979. The Prediction of Hydraulic Conductivity from Soil Moisture Suction Relationship. B. Sc. Thesis, University of Saskatchewan, Saskatoon, Canada.

[13] Segerlind, L. J. 1984. Applied Finite Element Analysis. John Wiley and Sons.

[14] Terzaghi, K. and Lacroix, Y., (1964) "Mission Dam An Earth and Rockfill Dam on Highly Compressible Foundation", Geotechnique, 14, pp. 14-50.

[15] U. S. Bureau of Reclamation, (1974) "Earth manual," U. S. Dept. of the Interior, $810 \mathrm{pp}$.

[16] Taylor RL, Brown CB, Darcy flow solutions with a free surface, Journal of Hydraulic Division, ASCE, 1967. 